Available online at www.sciencedirect.com

science@Directo

\section{JOURNAL OF PLANT PHYSIOLOGY}

www.elsevier.de/jplph

\title{
Hydrogen peroxide is necessary for abscisic acid- induced senescence of rice leaves
}

\author{
Kuo Tung Hung, Ching Huei Kao*
}

Department of Agronomy, National Taiwan University, Taipei, Taiwan, ROC

Received 16 March 2004; accepted 12 May 2004

KEYWORDS:

Abscisic acid;

$\mathrm{H}_{2} \mathrm{O}_{2}$

Leaf senescence;

Lipid peroxidation;

Oryza sativa

\begin{abstract}
Summary
The role of $\mathrm{H}_{2} \mathrm{O}_{2}$ in abscisic acid (ABA)-induced rice leaf senescence is investigated. ABA treatment resulted in $\mathrm{H}_{2} \mathrm{O}_{2}$ production in rice leaves, which preceded the occurrence of leaf senescence. Dimethylthiourea, a chemical trap for $\mathrm{H}_{2} \mathrm{O}_{2}$, was observed to be effective in inhibiting $A B A$-induced senescence, $A B A$-increased malondialdehyde (MDA) content, ABA-increased antioxidative enzyme activities (superoxide dismutase, ascorbate peroxidase, glutathione reductase and catalase), and ABA-decreased antioxidant contents (ascorbic acid and reduced glutathione) in rice leaves. Diphenyleneiodonium chloride (DPI) and imidazole (IMD), inhibitors of $\mathrm{NADPH}$ oxidase, and $\mathrm{KCN}$ and $\mathrm{NaN}_{3}$, inhibitors of peroxidase, prevented ABA-induced $\mathrm{H}_{2} \mathrm{O}_{2}$ production, suggesting NADPH oxidase and peroxidase are $\mathrm{H}_{2} \mathrm{O}_{2}$-generating enzymes in ABA-treated rice leaves. DPI, IMD, KCN, and $\mathrm{NaN}_{3}$ also inhibited ABApromoted senescence, ABA-increased MDA contents, ABA-increased antioxidative enzyme activities, and $A B A-d e c r e a s e d$ antioxidants in rice leaves. These results suggest that $\mathrm{H}_{2} \mathrm{O}_{2}$ is involved in $\mathrm{ABA}$-induced senescence of rice leaves.

(C) 2004 Elsevier $\mathrm{GmbH}$. All rights reserved.
\end{abstract}

\section{Introduction}

The plant hormone abscisic acid (ABA) is a sesquiterpenoid synthesized from xanthophylls (Creelman, 1989; Taylor et al., 2000; Seo and Koshiba, 2002) and appears to influence several physiological and developmental events (Creelman, 1989; Kende and Zeevaart, 1997). It has been suggested that $A B A$ is one of the most effective plant hormones in terms of promoting leaf senescence (Nooden, 1988). Applied ABA has been found to promote leaf senescence in a wide range of plant

Abbreviations: AOS, Active oxygen species; APOD, Ascorbate peroxidase; AsA, Ascorbic acid; CAT, Catalase; DMTU, Dimethylthiourea; DPI, Diphenyleneiodonium chloride; FW, Fresh weight; GR, Glutathione reductase; GSH, Reduced glutathione; MDA, Malondialdehyde; SOD, Superoxide dismutase

*Corresponding author. Fax: +886-2-23620879

E-mail address: kaoch@ntu.edu.tw (C.H. Kao). 
species (Nooden, 1988; Creelman, 1989). An increase in endogenous $A B A$ has been shown to coincide with senescence of leaves (Gepstein and Thimann, 1980; Yang et al., 2002).

Lipid peroxidation is considered to be an important mechanism of leaf senescence (Thompson et al., 1987). Active oxygen species (AOS) can initiate lipid peroxidation (Kellogg and Fridovich, 1975). It has been shown that $A B A$ causes generation of AOS including $\mathrm{H}_{2} \mathrm{O}_{2}$ (Guan et al., 2000; Pei et al., 2000; Jiang and Zhang, 2001; Hung and Kao, 2003) and lipid peroxidation expressed as malondialdehyde (MDA) production in plant cells (Bueno et al., 1998). Thus, ABA leads to oxidative stress in plant cells.

Recently, many researchers have focused on the functional aspects of $\mathrm{H}_{2} \mathrm{O}_{2} \cdot \mathrm{H}_{2} \mathrm{O}_{2}$ is a constituent of oxidative metabolism and is itself an AOS. It has been shown that $\mathrm{H}_{2} \mathrm{O}_{2}$ promotes leaf senescence (Parida et al., 1978; Mondal and Choudhuri, 1981; Begam and Choudhuri, 1992; Lin and Kao, 1998) and induction of senescence is accompanied by an increase in endogenous $\mathrm{H}_{2} \mathrm{O}_{2}$ content (Mondal and Choudhuri, 1981; Hung and Kao, 2003). Because $\mathrm{H}_{2} \mathrm{O}_{2}$ is relatively stable and diffusible through membrane, it is generally thought to serve as a signal molecule under various abiotic stresses (Chamnongpol et al., 1998; Neill et al., 2002), in acclimation to photooxidative stress (Karpinski et al., 1999), in plant-pathogen interactions (Levine et al., 1994), and in ABA-induced stomatal closure (Zhang et al., 2001).

We have previously shown that $A B A$ not only increases the content of $\mathrm{H}_{2} \mathrm{O}_{2}$ and the activities of superoxide dismutase (SOD), ascorbate peroxidase (APOD), glutathione reductase (GR), and catalase (CAT), but also causes a decrease in ascorbic acid (AsA) and glutathione (GSH) contents in rice leaves (Hung and Kao, 2003). Meanwhile, protein loss (senescence) and lipid peroxidation were observed in ABA-treated rice leaves (Hung and Kao, 2003). All these results suggest that $A B A$ causes oxidative stress and ABA-promoted senescence of rice leaves is mediated through oxidative stress. Here, we have examined the role of $\mathrm{H}_{2} \mathrm{O}_{2}$ as a connection between $\mathrm{ABA}$ and subsequent antioxidant defense and senescence in rice leaves.

\section{Materials and methods}

\section{Plant material and chemicals}

Rice (Oryza sativa L., cv. Taichung Native 1) was sterilized with $2.5 \%$ sodium hypochlorite for $15 \mathrm{~min}$ and washed extensively with distilled water. These seeds were then germinated in Petri dishes with wetted filter paper at $37^{\circ} \mathrm{C}$ under dark conditions. After $48 \mathrm{~h}$ incubation, uniformly germinated seeds were selected and cultivated in a $500 \mathrm{ml}$ beaker containing half-strength Kimura $B$ solution as described previously (Chu and Lee, 1989). The hydroponically cultivated seedlings were grown for 12 days in a Phytotron with natural light $30^{\circ} \mathrm{C}$ day $(12 \mathrm{~h}) / 25^{\circ} \mathrm{C}$ night $(12 \mathrm{~h})$ and $90 \%$ relative humidity. The apical $3 \mathrm{~cm}$ of the third leaf was used in all experiments. A group of ten segments was floated in a Petri dish containing $10 \mathrm{ml}$ of test solution. Incubation was carried out at $27^{\circ} \mathrm{C}$ in the dark.

\section{Determinations of protein, $\mathrm{H}_{2} \mathrm{O}_{2}$, lipid peroxidation, GSH, and AsA}

The senescence of detached rice leaves was followed by measuring the decrease of protein content. For protein extraction, leaf segments were homogenized in $50 \mathrm{mmoll}^{-1}$ sodium phosphate buffer $(\mathrm{pH}$ 6.8). The extracts were centrifuged at $17,600 g_{n}$ for $20 \mathrm{~min}$, and the supernatants were used for determination of protein by the method of Bradford (1976) and enzyme activities. The $\mathrm{H}_{2} \mathrm{O}_{2}$ content was measured colorimetrically as described by Jana and Choudhuri (1981). $\mathrm{H}_{2} \mathrm{O}_{2}$ was extracted by homogenizing leaf tissue with phosphate buffer $\left(50 \mathrm{mmol} \mathrm{l}^{-1}, \mathrm{pH}\right.$ 6.5) containing $1 \mathrm{mmol} \mathrm{l}^{-1}$ hydroxylamine. The homogenate was centrifuged at $6000 \mathrm{~g}_{n}$ for $25 \mathrm{~min}$. To determine $\mathrm{H}_{2} \mathrm{O}_{2}$ content, the extracted solution was mixed with $0.1 \%$ titanium sulphate in $20 \%(\mathrm{v} / \mathrm{v}) \mathrm{H}_{2} \mathrm{SO}_{4}$. The mixture was then centrifuged at $6000 g_{n}$ for $25 \mathrm{~min}$. The absorbance was measured at $410 \mathrm{~nm}$. The $\mathrm{H}_{2} \mathrm{O}_{2}$ content was calculated using the extinction coefficient $0.28 \mu \mathrm{mol}^{-1} \mathrm{~cm}^{-1}$. MDA, routinely used as an indicator of lipid peroxidation, was extracted with $5 \%(\mathrm{w} / \mathrm{v})$ trichloroacetic acid and determined according to Heath and Packer (1968). GSH in 3\% sulfosalicylic acid extract and AsA in $5 \%(\mathrm{w} / \mathrm{v})$ trichloroacetic acid extract were determined as described by Smith (1985) and Laws et al. (1983), respectively.

\section{Enzyme assays}

The enzyme assays in detail have been described previously (Hurng and Kao, 1994). CAT activity was assayed by measuring the initial rate of disappearance of $\mathrm{H}_{2} \mathrm{O}_{2}$ (Kato and Shimizu, 1987). The decrease in $\mathrm{H}_{2} \mathrm{O}_{2}$ was followed as the decline in absorbance at $240 \mathrm{~nm}$, and activity was calculated using the extinction coefficient 
[40 (mmol l-1 $)^{-1} \mathrm{~cm}^{-1}$ at $240 \mathrm{~nm}$ ] for $\mathrm{H}_{2} \mathrm{O}_{2}$ (Kato and Shimizu, 1987). SOD was determined according to Paoletti et al. (1986). APOD was determined according to Nakano and Asada (1981). The decrease in AsA concentration was followed as the decline in optical density at $290 \mathrm{~nm}$ and activity was calculated using the extinction coefficient [2.8 $\left(\mathrm{mmoll}^{-1}\right)^{-1} \mathrm{~cm}^{-1}$ at $\left.290 \mathrm{~nm}\right]$ for AsA. GR was determined by the method of Foster and Hess (1980). One unit of activity for CAT, SOD, APOD, and GR was defined as the amount of enzyme which degraded $1 \mu \mathrm{mol} \mathrm{H}_{2} \mathrm{O}_{2}$ per min, inhibited $50 \%$ the rate of $\mathrm{NADH}$ oxidation observed in control, degraded $1 \mu \mathrm{mol}$ of AsA per min, and decreased 1 $A_{340}$ per min, respectively.

\section{Statistical analysis}

The results presented were the mean of four replicates. Means were compared by either Student's $t$-test or Duncan's multiple range test at $5 \%$ level of significance.

\section{Results}

Yellowing is an obvious expression of leaf senescence and chlorophyll loss is often viewed as the principal criterion of senescence. The protein degradation during leaf senescence has been realized from earliest studies. We have shown that protein degradation precedes chlorophyll loss during rice leaf senescence (Kao, 1980). Thus, senescence of rice leaves in the present investigation was followed by measuring the decrease of protein. MDA is routinely used as an indicator of lipid peroxidation. The changes in protein and MDA contents in detached rice leaves treated with $45 \mu \mathrm{mol} \mathrm{l}^{-1}$ ABA in the dark are shown in Figs. 1A and $B$. The decrease in protein and increase in MDA was evident at $36 \mathrm{~h}$ after ABA treatment. Clearly, $A B A$ is effective in promoting senescence of rice leaves. ABA treatment resulted in an increase in $M D A$, indicating that $A B A$ brings about lipid peroxidation. Lipid peroxidation is caused by AOS (Kellogg and Fridovich, 1975; Thompson et al., 1987). ABA treatment also caused an increase in $\mathrm{H}_{2} \mathrm{O}_{2}$ content (Fig. 1C). The increase in $\mathrm{H}_{2} \mathrm{O}_{2}$ was evident at $24 \mathrm{~h}$ after treatment of $\mathrm{ABA}$, which preceded the decrease in protein and increase in MDA. These results suggest that $\mathrm{H}_{2} \mathrm{O}_{2}$ may play an important role in regulating the senescence of rice leaves induced by ABA.

To demonstrate the involvement of $\mathrm{H}_{2} \mathrm{O}_{2}$ in the effects induced by $A B A$ in rice leaves, namely the
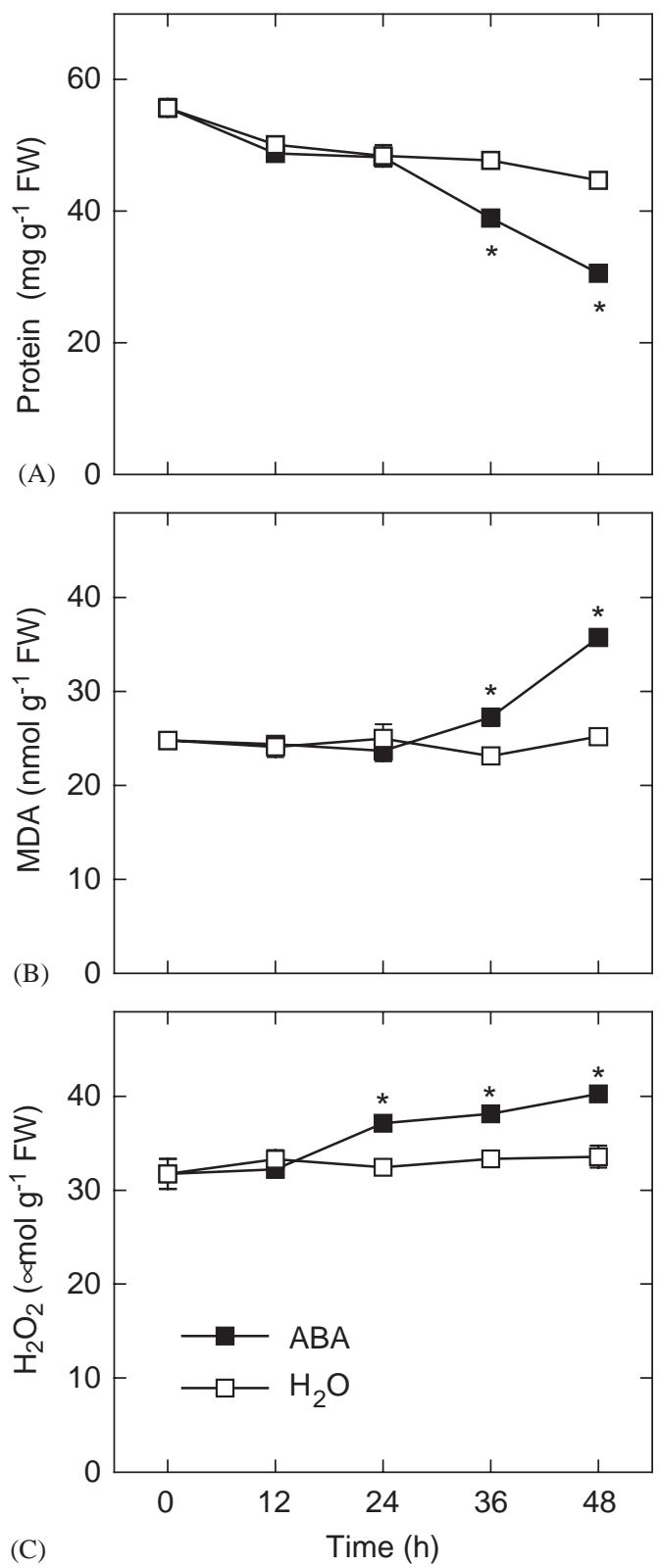

Figure 1. Changes in the contents of protein (A), MDA (B), and $\mathrm{H}_{2} \mathrm{O}_{2}(\mathrm{C})$ in rice leaves treated with either water or $45 \mu \mathrm{moll}^{-1} \mathrm{ABA}$ in the dark. Values are means $\pm \mathrm{SE}$ $(n=4)$. Asterisks represent values that are significant at $P<0.05$ level by Student's $t$-test when compared to water control.

decrease in protein content and the increase in MDA content, dimethylthiourea (DMTU), a chemical trap for $\mathrm{H}_{2} \mathrm{O}_{2}$ (de Agazio and Zacchini, 2001), was used. Detached rice leaves were incubated in a solution containing $45 \mu \mathrm{mol} \mathrm{l} \mathrm{l}^{-1} \mathrm{ABA}$ with or without $5 \mathrm{mmol}^{-1}$ DMTU. As indicated in Figs. $2 A$ and $B$, the decrease in protein and the increase in MDA in rice leaves caused by ABA were reduced by DMTU. Previously, we have shown that $A B A$ increased the 

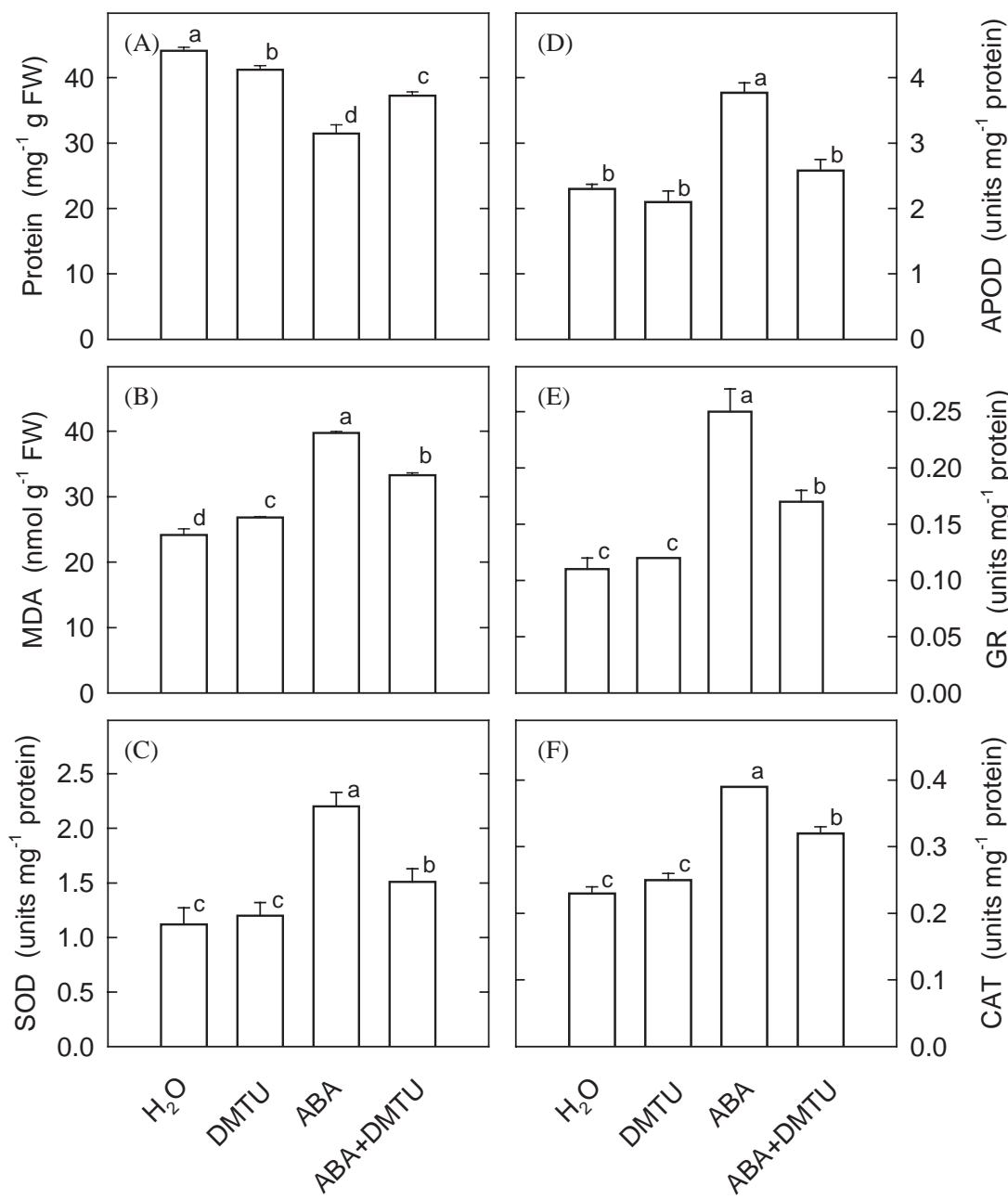

Figure 2. Effect of DMTU on the contents of protein (A), and MDA (B), and the activities of SOD (C), APOD (D), GR (E), and CAT $(F)$ in rice leaves treated with ABA. The concentrations of ABA and DMTU were $45 \mu \mathrm{mol} \mathrm{l}^{-1}$ and $5 \mathrm{mmol}^{-1}$, respectively. All measurements were determined 2 days after treatment in the dark. Values are means $\pm \operatorname{SE}(n=4)$. Value with the same letter are not significantly different at $P<0.05$ level, according to Duncan's multiple range test.

activities of SOD, APOD, GR, and CAT and decreased the contents of AsA and GSH in rice leaves (Hung and Kao, 2003). DMTU was also observed to be effective in inhibiting ABA-increased activities of SOD (Fig. 2C), APOD (Fig. 2D), GR (Fig. 2E), and CAT (Fig. 2F) and ABA-decreased contents of AsA (Fig. $3 \mathrm{~A}$ ) and GSH (Fig. 3B) in rice leaves.

AOS, originating from the plasma-membrane NADPH oxidase, which transfers electrons from cytoplasmic NADPH to $\mathrm{O}_{2}$ to form $\mathrm{O}_{2}^{-}$, followed by dismutation of $\mathrm{O}_{2}^{-}$to $\mathrm{H}_{2} \mathrm{O}_{2}$, has been a recent focus in AOS signaling. In several model systems investigated in plants, the oxidative burst and the accumulation of $\mathrm{H}_{2} \mathrm{O}_{2}$ appear to be mediated by the activation of plasma-membrane NADPH oxidase complex (Ogawa et al., 1997; del Río et al., 1998; Potikha et al., 1999; Pei et al., 2000; OrozcoCárdenas et al., 2001; Jiang and Zhang, 2002).
Some chemical inhibitors of the NADPH oxidase complex found in mammalian neutrophils, such as diphenyleneiodonium chloride (DPI) and imidazole (IMD), inhibit the pathogen-, elicitor-, wound-, and ABA-induced accumulation of $\mathrm{H}_{2} \mathrm{O}_{2}$ in plants (Levine et al., 1994; Auh and Murphy, 1995; Bestwick et al., 1977; Alvarez et al., 1998; Orozco-Cárdenas and Ryan, 1999; Jiang and Zhang, 2002). As shown in Fig. 4, when detached rice leaves were treated with a solution of DPI $\left(25 \mu \mathrm{moll}^{-1}\right)$ and IMD ( $\left.0.1 \mathrm{mmol} \mathrm{l}^{-1}\right)$, ABA-induced accumulation of $\mathrm{H}_{2} \mathrm{O}_{2}$ in rice leaves was reduced (Figs. $4 \mathrm{C}$ and F). DPI and $I M D$ also inhibited ABA-promoted leaf senescence (Figs. 4A and D), ABA-increased contents of MDA (Figs. 4B and $\mathrm{E}$ ) and activities of SOD (Figs. 5A and 6A), APOD (Figs. 5B and 6B), GR (Figs. 5C and 6C), and CAT (Figs. 5D and 6D), and ABA-decreased contents of AsA (Fig. 3A) and GSH (Fig. 3B). 

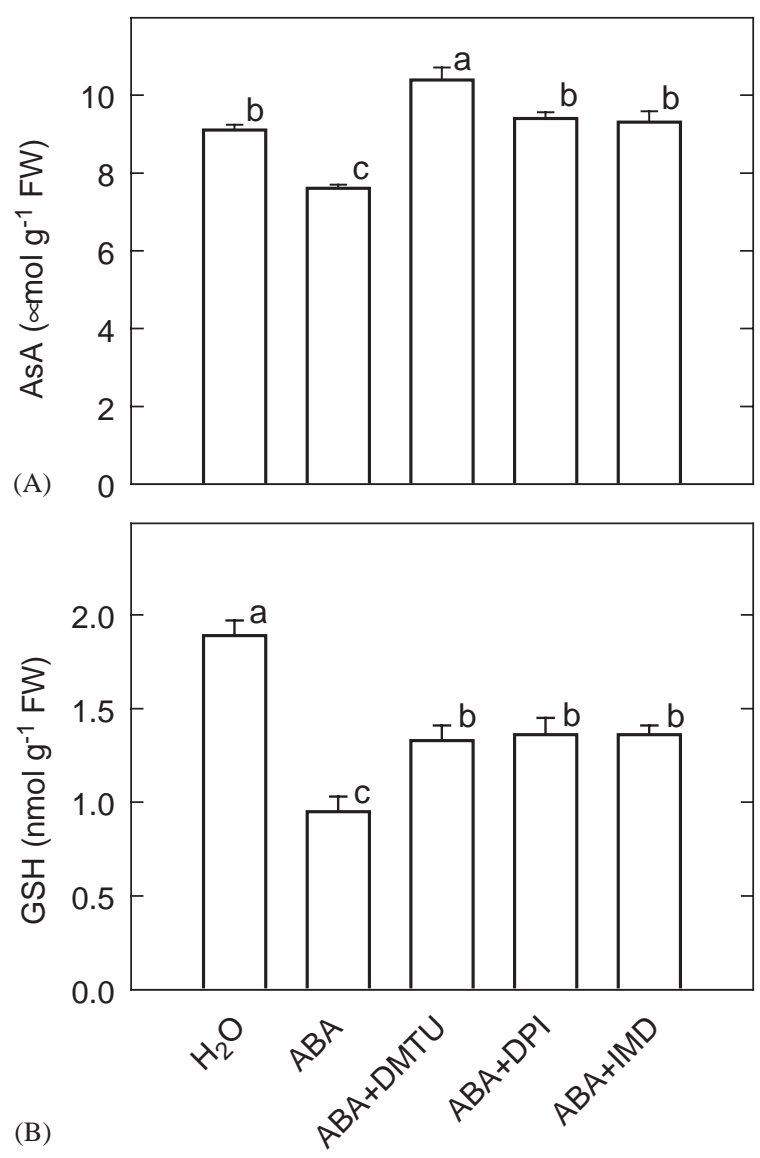

Figure 3. Effect of DMTU, DPI, and IMD on the contents of AsA (A) and GSH (B) in rice leaves treated with ABA. The concentrations of $A B A, D M T U, D P I$, and IMD were $45 \mathrm{moll}^{-1}, 5 \mathrm{mmoll}^{-1}, 25 \mu \mathrm{moll} \mathrm{l}^{-1}$, and $0.1 \mathrm{mmoll}^{-1}$, respectively. All measurements were determined 2 days after treatment in the dark. Values are means \pm SE $(n=4)$. Value with the same letter are not significantly different at $P<0.05$ level, according to Duncan's multiple range test.

Another potential enzymatic source of $\mathrm{H}_{2} \mathrm{O}_{2}$ production is cell wall peroxidase (Papadakis and Roubelakis-Angelakis, 1999; Blee et al., 2001). To test the possible involvement of cell wall peroxidase, peroxidase inhibitors such as $\mathrm{KCN}$ and $\mathrm{NaN}_{3}$ were used. As is well known, $\mathrm{KCN}$ and $\mathrm{NaN}_{3}$ are also inhibitors of mitochondria respiration. To distinguish the effect of $\mathrm{KCN}$ and $\mathrm{NaN}_{3}$ on respiration and peroxidase activity, the concentrations of $\mathrm{KCN}$ and $\mathrm{NaN}_{3}$ of $10 \mu \mathrm{mol} \mathrm{l}^{-1}$ and $1 \mathrm{mmol} \mathrm{l}^{-1}$, respectively, were used, since these concentrations did not inhibit the respiration rate of detached rice leaves (unpublished). Figure $7 \mathrm{C}$ shows that the addition of $\mathrm{KCN}$ and $\mathrm{NaN}_{3}$ to detached rice leaves restored the ABA-induced $\mathrm{H}_{2} \mathrm{O}_{2}$ production to control levels. $\mathrm{KCN}$ and $\mathrm{NaN}_{3}$ also inhibited ABA-promoted senescence (Fig. 7A), ABA-increased content of MDA (Fig. 7B) and activities of SOD (Fig. 8A), APOD (Fig. 8B), GR (Fig. 8C), and CAT (Fig. 8D), and ABA-decreased contents of AsA (Fig. 8E) and GSH (Fig. 8F).

\section{Discussion}

Pei et al. (2000) were the first to demonstrate the generation of $\mathrm{H}_{2} \mathrm{O}_{2}$ and its effects in guard cells caused by $\mathrm{ABA}$. In subsequent work, $\mathrm{ABA}$-induced increase in $\mathrm{H}_{2} \mathrm{O}_{2}$ has been reported for maize seedlings, rice roots, and rice leaves (Jiang and Zhang, 2001; Lin and Kao, 2001; Hung and Kao, 2003, Fig. 1C). On the other hand, ABA decreased the release of $\mathrm{H}_{2} \mathrm{O}_{2}$ from germinating radish seeds (Schopfer et al., 2001). It seems that $\mathrm{H}_{2} \mathrm{O}_{2}$ generation is not a common response to $A B A$ and this response is not confined to guard cells.

In guard cells, $A B A$-induced $\mathrm{H}_{2} \mathrm{O}_{2}$ generation is regulated by plasma-membrane NADPH oxidase (Pei et al., 2000; Zhang et al., 2001). Recently, Jiang and Zhang (2002) also reported that plasmamembrane NADPH oxidase is involved in ABA- and water stress-induced antioxidant defense in leaves of maize seedlings. Here, we show that DPI and IMD, inhibitors of NADPH oxidase (Levine et al., 1994; Auh and Murphy, 1995; Bestwick et al., 1977; Alvarez et al., 1998; Orozco-Cárdenas and Ryan, 1999; Pei et al., 2000; Orozco-Cárdenas et al., 2001; Jiang and Zhang, 2002), reduced ABAinduced $\mathrm{H}_{2} \mathrm{O}_{2}$ production (Figs. $4 \mathrm{C}$ and $\mathrm{F}$ ) and lipid peroxidation (Figs. $4 B$ and $E$ ), ABA-promoted senescence (Figs. 4A and D), ABA-increased antioxidative enzyme activities (Figs. 5 and 6 ), and ABA-decreased antioxidants (Fig. 3 ) in rice leaves. Similar results were obtained by using DMTU, a chemical trap for $\mathrm{H}_{2} \mathrm{O}_{2}$ (Figs. 2 and 3). Furthermore, the increase in $\mathrm{H}_{2} \mathrm{O}_{2}$ content by $A B A$ was observed to be preceded the occurrence of leaf senescence and the increase in MDA content (Figs. $1 \mathrm{~A}$ and $\mathrm{C}$ ). It appears that $\mathrm{H}_{2} \mathrm{O}_{2}$ is involved in ABAinduced senescence of rice leaves and that NADPH oxidase in rice leaf cells is involved in $A B A$-induced $\mathrm{H}_{2} \mathrm{O}_{2}$ production.

It has been shown that a high concentration of DPI can affect other enzymes potentially involved in the generation of AOS, including cell wall peroxidase and nitric oxide synthase (Bolwell et al., 1998; Orozco-Cárdenas et al., 2001; Schopfer et al., 2001). The fact that ABA-induced $\mathrm{H}_{2} \mathrm{O}_{2}$ accumulation in rice leaves can be inhibited by low concentration $\left(25 \mu \mathrm{mol} \mathrm{l}^{-1}\right) \mathrm{DPI}$, and can be inhibited by both DPI and IMD strongly suggest that ABAdependent $\mathrm{H}_{2} \mathrm{O}_{2}$ generation originated, at least in part, from plasma membrane NADPH oxidase. 

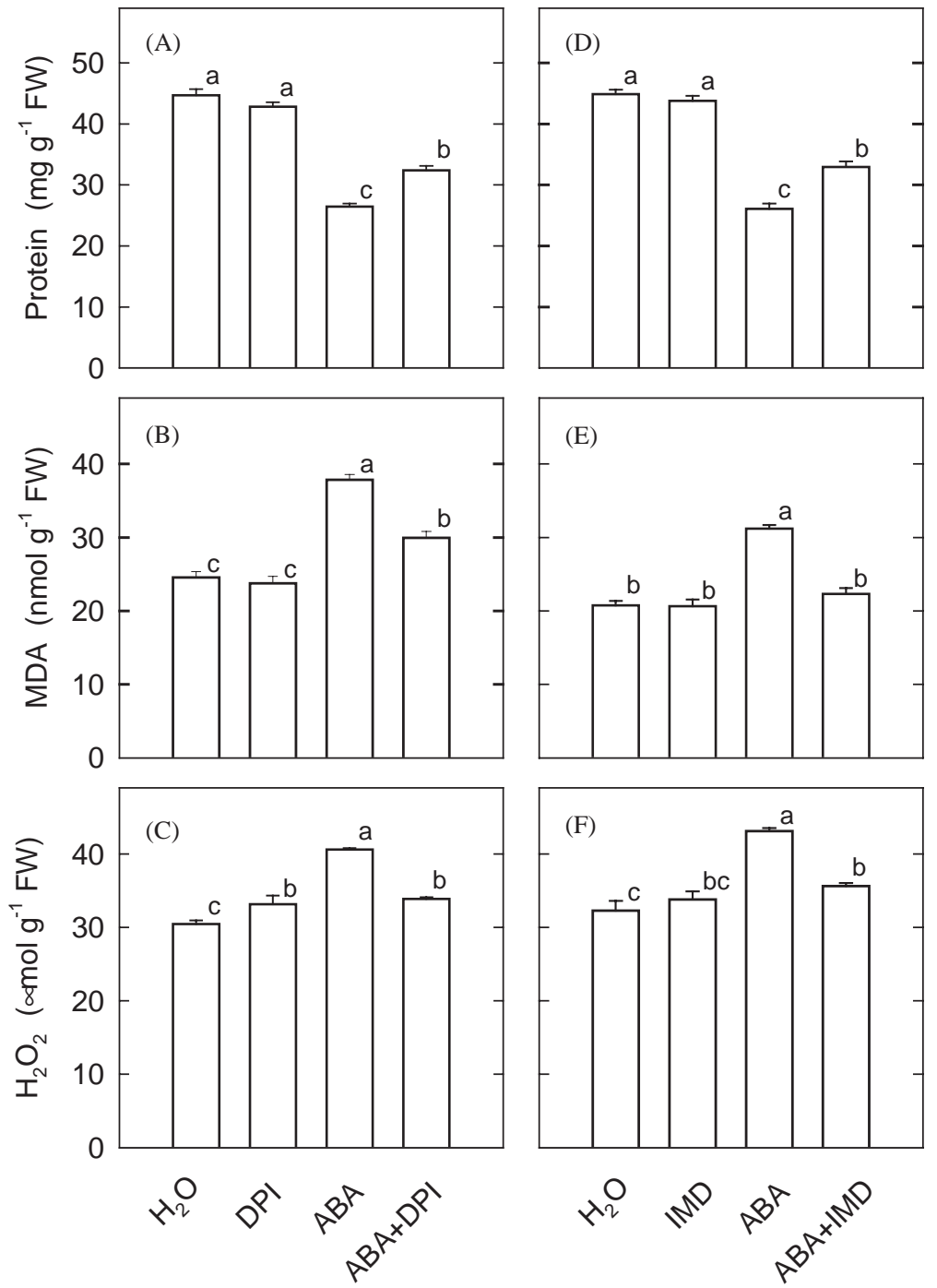

Figure 4. Effect of DPI and IMD on the contents of protein (A, D), and MDA (B, E), and $\mathrm{H}_{2} \mathrm{O}_{2}(C, F)$ in rice leaves treated with ABA. The concentrations of ABA, DPI, and IMD were $45,25 \mu \mathrm{moll}^{-1}$, and $0.1 \mathrm{mmoll}^{-1}$, respectively. All measurements were determined 2 days after treatment in the dark. Values are means $\pm \operatorname{SE}(n=4)$. Value with the same letter are not significantly different at $P<0.05$ level, according to Duncan's multiple range test.

Recently, a cell wall peroxidase has been identified in French bean (Bolwell et al., 1998; Blee et al., 2001), and a potentially peroxidasemediated $\mathrm{H}_{2} \mathrm{O}_{2}$ production has been demonstrated in Arabidopsis cultures challenged with a fungal elicitor (Bolwell et al., 2002). Arabidopsis plants transformed with an antisense bean peroxidase construct are hypersensitive with a fungal elicitor (Bolwell et al., 2002). Here, we show that $\mathrm{KCN}$ and $\mathrm{NaN}_{3}$, inhibitors of peroxidase, prevented ABAinduced $\mathrm{H}_{2} \mathrm{O}_{2}$ production (Fig. $7 \mathrm{C}$ ) and lipid peroxidation (Fig. 7B), ABA-promoted senescence (Fig. 7A), ABA-increased antioxidative enzyme activities (Figs. 8(A)-(D)), and ABA-decreased antioxidants in rice leaves (Figs. $8 \mathrm{E}$ and $\mathrm{F}$ ). It appears that peroxidase is another $\mathrm{H}_{2} \mathrm{O}_{2}$-generating enzyme in $A B A$-treated rice leaves. However, the endogenous rice peroxidase has yet to be identified.

Plasma-membrane NADPH oxidase transfers electrons from cytoplasmic NADPH to $\mathrm{O}_{2}$ to form $\mathrm{O}_{2}^{-}$, which is then dismutated to $\mathrm{H}_{2} \mathrm{O}_{2}$ by the action of apoplastic SOD. It has been shown that $\mathrm{NaN}_{3}$ inhibits apoplastic Cu-Zn SOD (Ogawa et al., 1997). Furthermore, KCN has the ability to scavenge $\mathrm{H}_{2} \mathrm{O}_{2}$ (Baker et al., 1998). It appears that $\mathrm{KCN}$ and $\mathrm{NaN}_{3}$ are not fully specific to peroxidase, which would explain the results that the addition of $\mathrm{KCN}$ and $\mathrm{NaN}_{3}$ to detached rice leaves restored the ABA-induced $\mathrm{H}_{2} \mathrm{O}_{2}$ production to control levels (Fig. 7C).

In plants, polyamines are thought to play an important role in growth, development and stress 

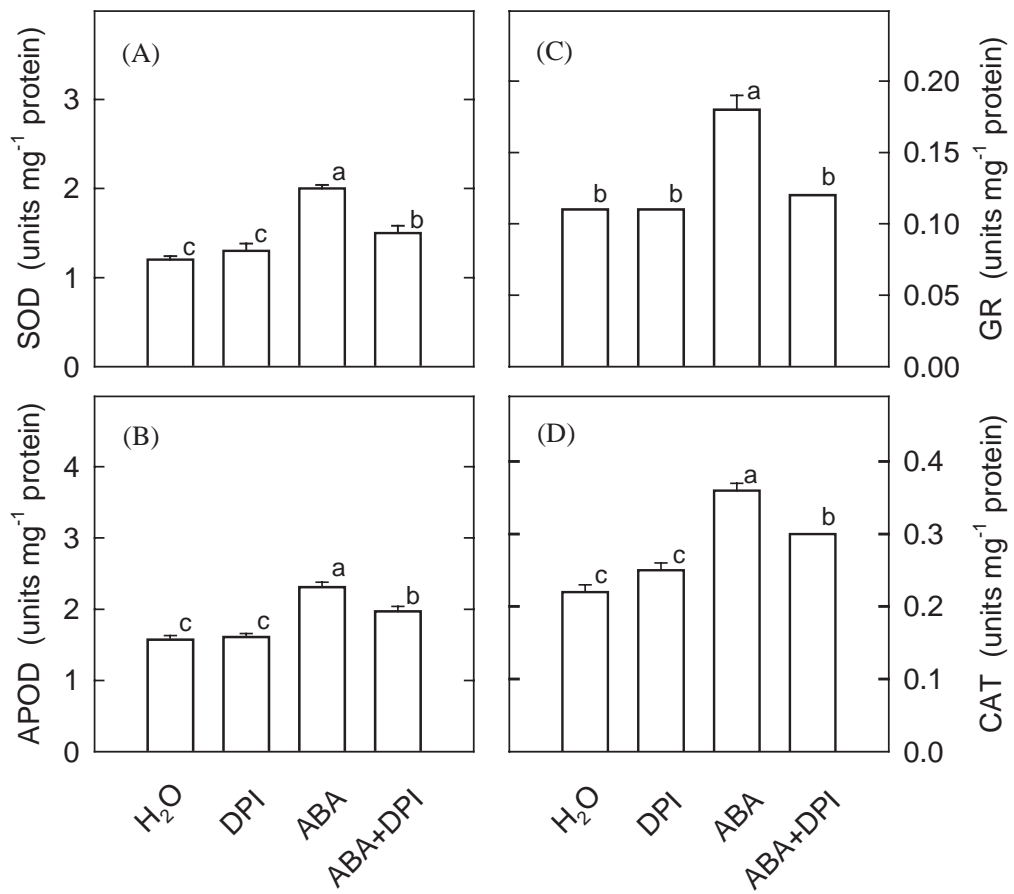

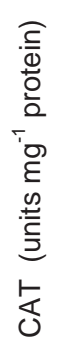

Figure 5. Effect of DPI on the activies of SOD (A), APOD (B), GR (C), and CAT (D) in rice leaves treated with ABA. The concentrations of ABA and DPI were 45 and $25 \mu \mathrm{mol} \mathrm{l}^{-1}$, respectively. All measurements were determined 2 days after treatment in the dark. Values are means \pm SE $(n=4)$. Value with the same letter are not significantly different at $P<0.05$ level, according to Duncan's multiple range test.
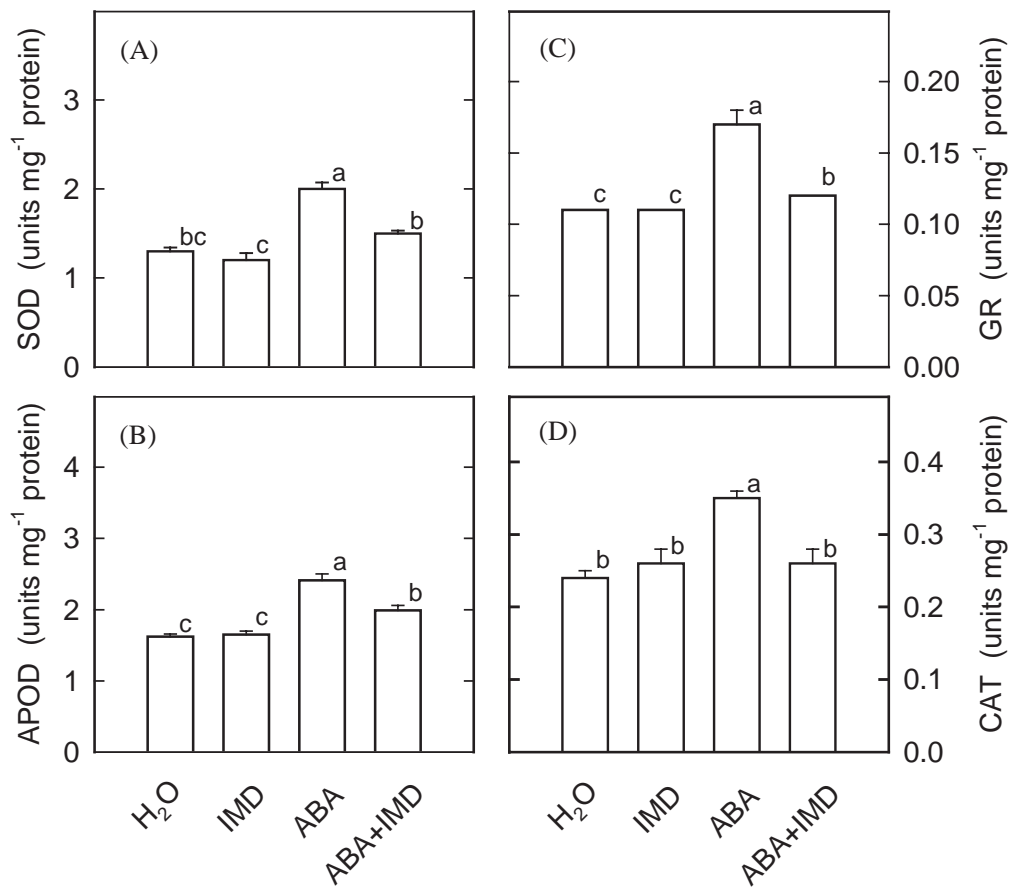

Figure 6. Effect of IMD on the activies of SOD (A), APOD (B), GR (C), and CAT (D) in rice leaves treated with ABA. The concentrations of $A B A$ and IMD were $45 \mu \mathrm{mol} \mathrm{I}^{-1}$ and $0.1 \mathrm{mmoll}^{-1}$, respectively. All measurements were determined 2 days after treatment in the dark. Values are means $\pm \operatorname{SE}(n=4)$. Value with the same letter are not significantly different at $P<0.05$ level, according to Duncan's multiple range test. 

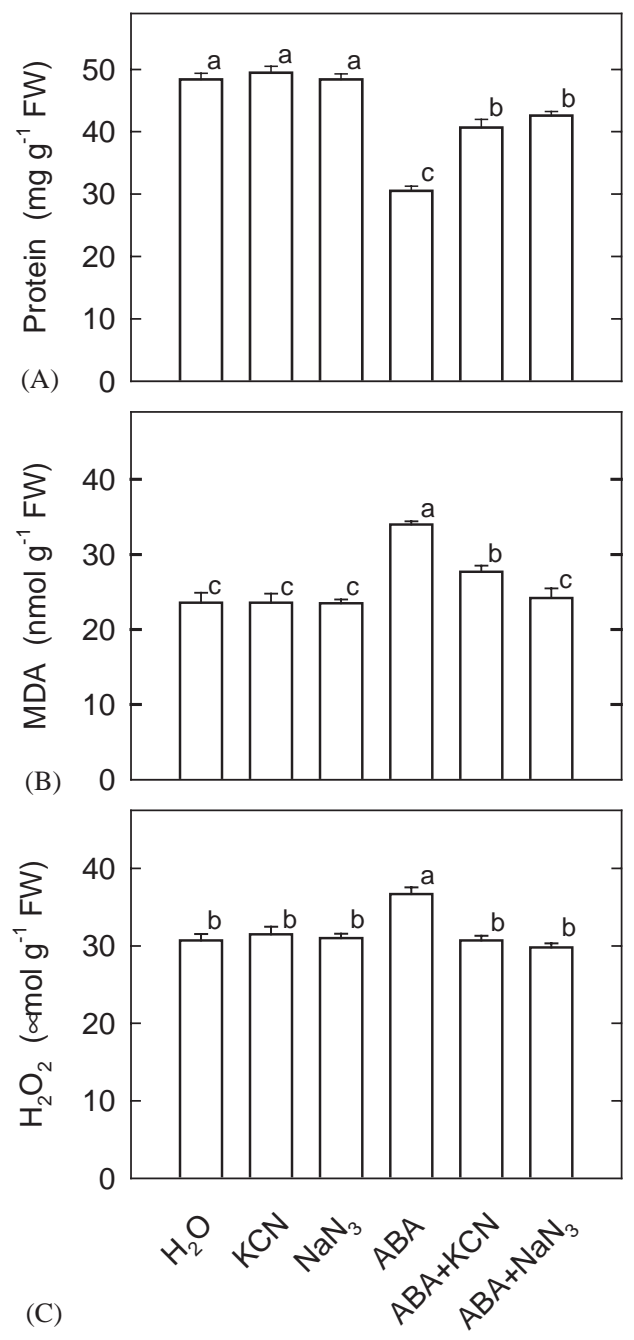

Figure 7. Effect of $\mathrm{KCN}$ and $\mathrm{NaN}_{3}$ on the contents of protein (A), and MDA (B), and $\mathrm{H}_{2} \mathrm{O}_{2}$ (C) in rice leaves treated with $A B A$. The concentrations of $A B A, K C N$, and $\mathrm{NaN}_{3}$ were $45,10 \mu \mathrm{moll}^{-1}$, and $1 \mathrm{mmoll}^{-1}$, respectively. All measurements were determined 2 days after treatment in the dark. Values are means $\pm \operatorname{SE}(n=4)$. Value with the same letter are not significantly different at $P<0.05$ level, according to Duncan's multiple range test.

response (Walden et al., 1997). It has been shown that $\mathrm{H}_{2} \mathrm{O}_{2}$ produced by diamine or polyamine oxidase induced hypersensitive cell death in plants (Yoda et al., 2003). Previously, we have shown that ABA treatment had no effect on polyamine content in rice leaves (Chen and Kao, 1991). Thus, diamine or polyamine oxidase is unlikely to be affected by $A B A$ in rice leaves. An alternative source for $\mathrm{H}_{2} \mathrm{O}_{2}$ includes oxalate oxidase, an enzyme that degrades oxalate to $\mathrm{CO}_{2}$ and $\mathrm{H}_{2} \mathrm{O}_{2}$ (Dumas et al., 1995). Oxalate oxidase gene expression is induced by salt stress, salicylate, and methyl jasmonate (Hurkman and Tanaka, 1996). It is not known whether ABA will activate oxalate oxidase in rice leaves. Further work is necessary to clarify this possibility.

Results observed in the present study suggest that NADPH oxidase, which shows sensitivity to DPI and IMD, and peroxidase, which is sensitive to $K C N$ and $\mathrm{NaN}_{3}$, are operating in $\mathrm{ABA}$-treated rice leaves. These two $\mathrm{H}_{2} \mathrm{O}_{2}$-generating enzymes were also observed in tobacco protoplasts (Papadakis and Roubelakis-Angelakis, 1999). It appears that when rice leaves are treated with $\mathrm{ABA}, \mathrm{H}_{2} \mathrm{O}_{2}$ is generated in the apoplast. Because apoplast has only a small proportion of the cell's antioxidant capacity, $\mathrm{H}_{2} \mathrm{O}_{2}$ will rapidly move into the cell to exert its effect on senescence. It has been suggested that peroxiporins or water channels (aquaporins) may serve as conduits for trans-membrane $\mathrm{H}_{2} \mathrm{O}_{2}$ transport (Neill et al., 2002). Thus, $\mathrm{H}_{2} \mathrm{O}_{2}$ can function as a mobile signal in ABA-treated rice leaves, but whether $\mathrm{H}_{2} \mathrm{O}_{2}$ is the sole signal remains to be determined.

When detached rice leaves are used to study senescence, wounding is always a problem. However, in the present study, each long and narrow rice leaf was cut transversely, thus the area of wounding was very small. Therefore, $\mathrm{H}_{2} \mathrm{O}_{2}$ generation and senescence of detached leaves induced by $A B A$ are unlikely to be complicated by the wounding effect. Since $A B A$ is known to inhibit ethylene production in detached rice leaves (Kao and Yang, 1983), ABA-induced $\mathrm{H}_{2} \mathrm{O}_{2}$ production and senescence do not seem to be mediated through ethylene production.

The mechanism of AOS production and the molecules involved have been well investigated in animal cells, particularly in neutrophils. The NADPH oxidase complex, which consists of many components, is responsible for AOS production in neutrophil cells, and is activated by the binding of posphatidylinositol 3-phosphate to one of the components (Ellson et al., 2001). Phosphatidylinositol 3-phosphate is a product of phosphatidylinositol 3-kinase, which phosphorylates the D-3 position of phosphoinositides. Recently, Jung et al. (2002) and Park et al. (2003) demonstrated that wortmannin or LY 294002, inhibitors of phosphatidylinositol 3-kinase, inhibited $A B A$-induced $\mathrm{H}_{2} \mathrm{O}_{2}$ production and stomatal closing and $\mathrm{H}_{2} \mathrm{O}_{2}$ partially reversed the effects of wortmannin or LY 294002 on ABA-induced stomatal closing. They suggested that phosphatidylinositol 3-phosphate is important in NADPH oxidase-mediated $\mathrm{H}_{2} \mathrm{O}_{2}$ production during ABA-induced stomatal closing. We have preliminary data indicating that wortmannin and $\mathrm{LY} 294002$ prevented $A B A$-induced $\mathrm{H}_{2} \mathrm{O}_{2}$ production and $A B A$ promoted senescence in rice leaves (Hung and Kao, unpublished observation). Work in this direction is presently under further investigation. 

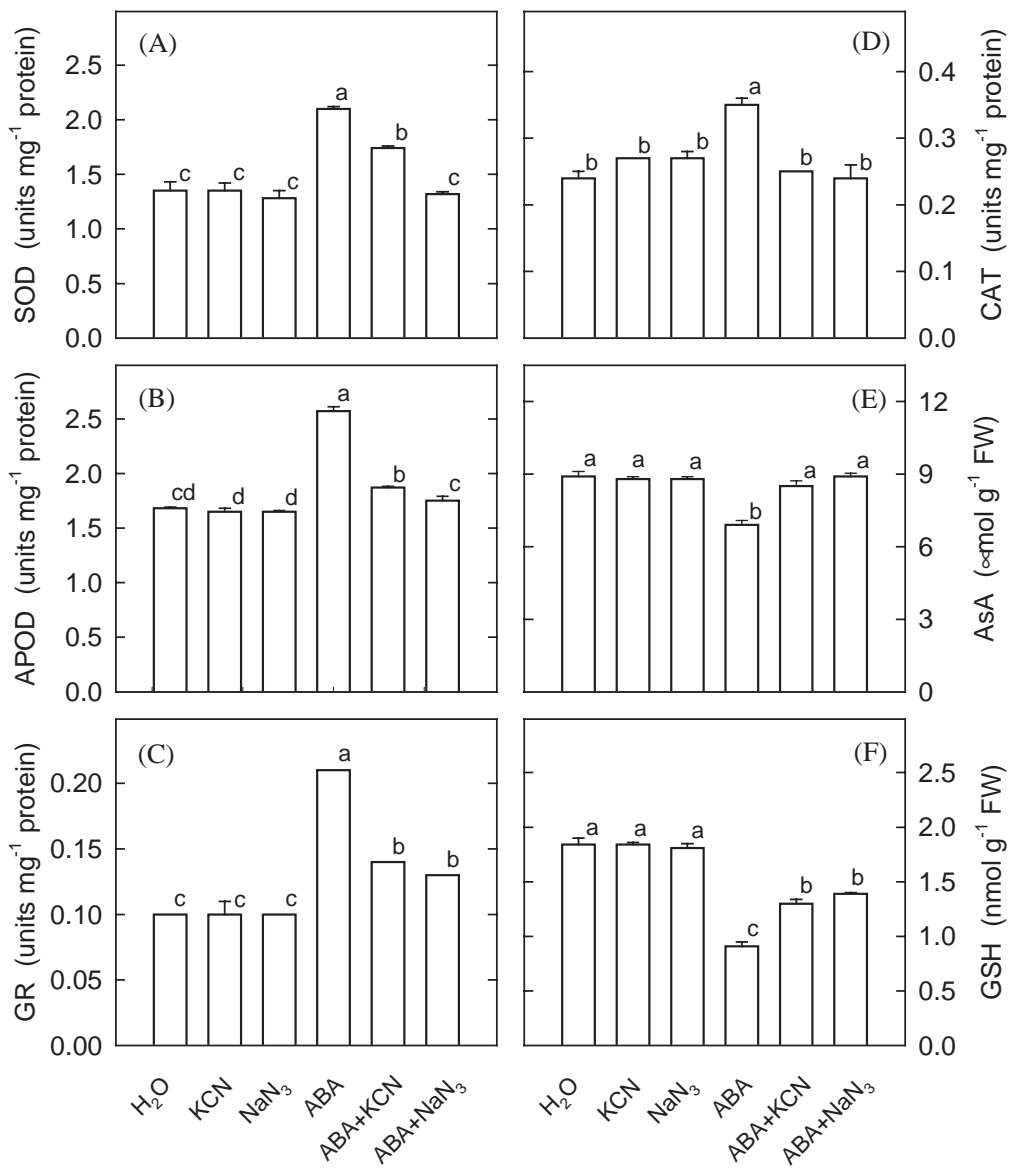

Figure 8. Effect of KCN and $\mathrm{NaN}_{3}$ on the activies of SOD (A), APOD (B), GR (C), and CAT (D) and the contents of AsA (E) and GSH (F) in rice leaves treated with ABA. The concentrations of $A B A, K C N$, and $\mathrm{NaN}_{3}$ were $45,10 \mu \mathrm{moll}^{-1}$, and $1 \mathrm{mmol} \mathrm{l}^{-1}$, respectively. All measurements were determined 2 days after treatment in the dark. Values are means $\pm \mathrm{SE}$ $(n=4)$. Value with the same letter are not significantly different at $P<0.05$ level, according to Duncan's multiple range test.

\section{Acknowledgements}

This work was supported by grant NSC 90-2313-B002-267 from the National Science Council of the Republic of China.

\section{References}

Alvarez ME, Penell RI, Meijer PJ, Ishikawa A, Dixon RA, Lamb C. Reactive oxygen intermediates mediate a systemic signal network in the establishment of plant immunity. Cell 1998;92:773-84.

Auh CK, Murphy TM. Plasma membrane redox enzyme is involved in the synthesis of $\mathrm{O}_{2}^{-}$and $\mathrm{H}_{2} \mathrm{O}_{2}$ by Phytophthora elicitor-stimulated rose cells. Plant Physiol 1995;107:1241-7.

Baker CJ, Deahl K, Domek JM, Orlandi EW. Oxygen metabolism in plant/bacteria interactions: effect of DPI on the pseudo-NAD(P)H oxidase activity of peroxidase. Biochem Biophys Res Commun 1998;252:461-4.

Begam $\mathrm{HH}$, Choudhuri MA. $\mathrm{H}_{2} \mathrm{O}_{2}$ metabolism during senescence of two submerged angiosperm Hydrilla and Ottelia: changes in enzyme activities in light and darkness. Biochem Physiol Pflanzen 1992;188:105-15.

Bestwick CS, Brown IR, Bennett MHR, Mansfield JW. Localization of hydrogen peroxide accumulation during the hypersensitive reaction of lettuce cells to Pseudomonas syringae pv phaseolicola. Plant Cell 1977;9:209-21.

Blee KA, Jupe SC, Richard G, Bolwell GP. Molecular identification and expression of the peroxidase responsible for the oxidative burst in French bean (Phaseolus vulgaris $\mathrm{L}$ ) and related members of the gene family. Plant Mol Biol 2001;47:607-20.

Bolwell GP, Davies DR, Gerrish C, Auh CK, Murphy TM. Comparative biochemistry of the oxidative burst produced by rose and French bean cells reveals two distinct mechanisms. Plant Physiol 1998;116: 1374-85. 
Bolwell GP, Bindschedler LV, Blee KA, Butt VS, Davies DR, Gardner SL, Genrrish C, Minibayeva F. The apoplastic oxidative burst in response to biotic stress in plants: a three-component system. J Exp Bot 2002;53:1367-76.

Bradford MM. A rapid and sensitive method for the quantitation of microgram quantities of protein utilizing the principle of protein-dye binding. Anal Biochem 1976;72:248-54.

Bueno P, Piqueras A, Kurepa J, Savouré A, Verbruggen N, Van Montagu $M$, Inzé $D$. Expression of antioxidant enzymes in response to abscisic acid and high osmoticum in tobacco BY-2 cell cultures. Plant Sci 1998;138:27-34.

Chamnongpol S, Willekens $\mathrm{H}$, Moeder W, Langebartels $\mathrm{C}$, Sandermann H, Van Montagu M, Inzé D, Van Camp W. Defense activation and enhanced pathogen tolerance induced by $\mathrm{H}_{2} \mathrm{O}_{2}$ in transgenic tobacco. Proc Natl Acad Sci USA 1998;95:5818-23.

Chen $\mathrm{CT}$, Kao CH. Senescence of rice leaves XXX. Levels of endogenous polyamines and dark-induced senescence of rice leaves. Plant Cell Physiol 1991;32:935-41.

Chu C, Lee TM. The relationship between ethylene biosynthesis and chilling tolerance in seedlings of rice (Oryza sativa). Bot Bull Acad Sin 1989;30:263-73.

Creelman RA. Abscisic acid physiology and biosynthesis in higher plants. Physiol Plant 1989;75:131-6.

de Agazio M, Zacchini M. Dimethylthiourea, a hydrogen peroxide trap, partially prevents stress effects and ascorbate peroxidase increase in spermidine-treated maize roots. Plant Cell Environ 2001;24:237-44.

del Río LA, Pastori GM, Palma JM, Sandalio LM, Sevilla F, Corpas FJ, Jiménez A, López-Huartas E, Hernández JA. The activated oxygen role of peroxisomes in senescence. Plant Physiol 1998;116:1195-200.

Dumas B, Freyssinet G, Pallett KE. Tissue-specific expression of germin-like oxalate oxidase during development and fungal infection of barley seedlings. Plant Physiol 1995;107:1091-6.

Ellson CD, Gobert-Gosse S, Anderson KE, Davidson K, Erdjument-Bromage $H$, Tempst $P$, Thuring JW, Cooper MA, Lim Z-Y, Holmes AB, Gaffney PRJ, Coadwell J, Chilvers ER, Hawkins PT, Stephens LR. Ptdlns(3)P regulates the neutrophil oxidase complex by binding to the PX domain of $\mathrm{p} 40^{\text {phox }}$. Nat Cell Biol 2001;3:679-82.

Foster JG, Hess JL. Responses of superoxide dismutase and glutathione reductase activities in cotton leaf tissue exposed to an atmosphere enriched in oxygen. Plant Physiol 1980;66:482-7.

Gepstein S, Thimann KV. Changes in the abscisic acid content of oat leaves during senescence. Proc Natl Acad Sci USA 1980;77:2050-3.

Guan L, Zhao J, Scandalios JG. Cis-elements and transfactors that regulate expression of the maize Cat1 antioxidant gene in response to $\mathrm{ABA}$ and osmotic stress: $\mathrm{H}_{2} \mathrm{O}_{2}$ is the likely intermediary signaling molecule for the response. Plant J 2000;22:87-95.

Heath RL, Packer L. Photoperoxidation in isolated chloroplasts. I. Kinetics and stoichiometry of fatty acid peroxidation. Arch Biochem Biophys 1968;125:189-98.

Hung KT, Kao CH. Nitric oxide counteracts the senescence of rice leaves induced by abscisic acid. J Plant Physiol 2003;160:871-9.

Hurkman WJ, Tanaka CK. Effect of salt stress on germin gene expression in barley roots. Plant Physiol 1996;110:971-7.

Hurng WP, Kao $\mathrm{CH}$. Effect of flooding on the activities of some enzymes of activated oxygen metabolism, the levels of antioxidants, and lipid peroxidation in senescing tobacco leaves. Plant Growth Regul 1994;14:37-44.

Jana S, Choudhuri MA. Glycolate metabolism of three submerged aquatic angiosperm during aging. Aquat Bot 1981;12:345-54.

Jiang $M$, Zhang J. Effect of abscisic acid on active oxygen species, antioxidative defense system and oxidative damage in leaves of maize seedlings. Plant Cell Physiol 2001;42:1265-73.

Jiang $M$, Zhang J. Involvement of plasma membrane NADPH oxidase in abscisic acid- and water stressinduced antioxidant defense in leaves of maize seedlings. Planta 2002;215:1022-30.

Jung J-Y, Kim Y-W, Kwak JM, Hwang J-U, Young J, Schroeder JI, Hwang I, Lee Y. Phosphatidylinositol 3and 4-phosphate are required for normal stomatal movements. Plant Cell 2002;14:2397-412.

Kao CH. Senescence of rice leaves IV Influence of benzyladenine on chlorophyll degradation. Plant Cell Physiol 1980;21:1255-62.

Kao CH, Yang SF. Role of ethylene in the senescence of detached rice leaves. Plant Physiol 1983;73:881-5.

Karpinski S, Reynolds H, Karpinska B, Wingsle G, Creissen G, Mullineaux P. Systemic signaling and acclimation in response to excess excitation energy in Arabidopsis. Science 1999;84:654-7.

Kato M, Shimizu S. Chlorophyll metabolism in higher plants. VII. Chlorophyll degradation in senescing tobacco leaves: phenolic-dependent peroxidative degradation. Can J Bot 1987;65:729-35.

Kellogg EW, Fridovich I. Superoxide, hydrogen peroxide, and singlet oxygen in lipid peroxidation by xanthine oxidase system. J Biol Chem 1975;250: 8812-7.

Kende $\mathrm{H}$, Zeevaart JAD. The five classical plant hormones. Plant Cell 1997;9:1197-210.

Laws MY, Charles SA, Halliwell B. Glutathione and ascorbic acid in spinach chloroplasts: the effect of hydrogen peroxide and of paraquat. Biochem J 1983;210:899-903.

Levine A, Tenhaken R, Dixon RA, Lamb CJ. $\mathrm{H}_{2} \mathrm{O}_{2}$ from the oxidative burst orchestrates the plant hypersensitive disease resistance response. Cell 1994;79:583-93.

Lin JN, Kao CH. Effect of oxidative stress by hydrogen peroxide on senescence of rice leaves. Bot Bull Acad Sin 1998;39:161-5.

Lin CC, Kao CH. Abscisic acid induced changes in cell wall peroxidase activity and hydrogen peroxide level in roots of rice seedlings. Plant Sci 2001;160:323-9. 
Mondal R, Choudhuri MA. Role of hydrogen peroxide in senescence of excised leaves of rice and maize. Biochem Physiol Pflanzen 1981;176:700-9.

Nakano Y, Asada K. Hydrogen peroxide is scavenged by ascorbate-specific peroxidase in spinach chloroplasts. Plant Cell Physiol 1981;22:867-80.

Neill SJ, Desikan R, Clarke A, Hurst RD, Hancock JT. Hydrogen peroxide and nitric oxide as signalling molecules in plants. J Exp Bot 2002;53:1237-47.

Nooden LD. Abscisic acid, auxin and other regulators of senescence. in: Nooden LD, editor. Senescence and aging in plants. San Diego: Academic Press Inc.; 1988. p. 329-68.

Ogawa K, Kanematsu S, Asada K. Generation of superoxide anion and localization of CuZn-superoxide dismutase in the vascular tissue of spinach hypocotyls: their association with lignification. Plant Cell Physiol 1997;38:1118-26.

Orozco-Cárdenas M, Ryan CA. Hydrogen peroxide is generated systemically in plant leaves by wounding and systemin via the octadecanoid pathway. Proc Natl Acad Sci USA 1999;96:6553-7.

Orozco-Cárdenas M, Narváez-Vásquez J, Ryan CA. Hydrogen peroxide acts as a second messenger for the induction of defense genes in tomato plants in response to wounding, systemin, and methyl jasmonate. Plant Cell 2001;13:179-91.

Paoletti F, Aldinucci D, Mocali A, Capparini A. A sensitive spectrophotometric method for the determination of superoxide dismutase activity in tissue extracts. Anal Biochem 1986;154:536-41.

Papadakis AK, Roubelakis-Angelakis KA. The generation of active oxygen species differs in tobacco and grapevine mesophyll protoplasts. Plant Physiol 1999;121:197-205.

Parida RK, Kat M, Mishra D. Enhancement of senescence in excised rice leaves by hydrogen peroxide. Can J Bot 1978;56:2937-41.

Park KY, Jung J-Y, Park J, Hwang J-U, Kim Y-W, Hwang I, Lee Y. A role for phosphatidylinositol 3-phosphate in abscisic acid-induced reactive oxygen species generation in guard cells. Plant Physiol 2003;132:92-8.
Pei ZM, Murata N, Benning G, Thomine S, Klüsener B, Allen GJ, Grill E, Schroeder JI. Calcium channels activated by hydrogen peroxide mediate abscisic acid signaling in guard cells. Nature 2000;406:731-4.

Potikha TS, Collins CC, Johnson DI, Delmer DP, Levine A. The involvement of hydrogen peroxide in the differentiation of secondary walls in cotton fibers. Plant Physiol 1999;119:849-58.

Schopfer P, Plachy C, Frahry G. Release of reactive oxygen intermediates (superoxide radicals, hydrogen peroxide, and hydroxyl radicals) and peroxidase in germinating radish seeds controlled by light, gibberellin, and abscisic acid. Plant Physiol 2001;125:1591-602.

Seo M, Koshiba T. Complex regulation of ABA biosynthesis. Trends Plant Sci 2002;7:41-8.

Smith IK. Stimulation of glutathione synthesis in photorespiring plants by catalase inhibitors. Plant Physiol 1985;79:1044-7.

Taylor LB, Burbridge A, Thompson AJ. Control of abscisic acid synthesis. J Exp Bot 2000;21:1563-74.

Thompson JE, Legge RL, Barber RF. The role of free radical in senescence and wounding. New Phytol 1987;105:317-44.

Walden R, Cordeiro A, Tiburcio AF. Polyamines: small molecules triggering pathways in plant growth and development. Plant Physiol 1997;113:1009-13.

Yang J, Zhang J, Wang Z, Zhu Q, Liu L. Abscisic acid and cytokinins in the root exudates and leaves and their relationship to senescence and remobilization of carbon reserves in rice subjected to water stress during grain filling. Planta 2002;215: 645-52.

Yoda H, Yamaguchi Y, Sano H. Induction of hypersensitive cell death by hydrogen peroxide produced through polyamine degradation in tobacco plants. Plant Physiol 2003;132:1973-81.

Zhang X, Zhang L, Dong F, Gao J, Galbraite DW, Song C-P. Hydrogen peroxide is involved in abscisic acid-induced stomatal closure in Vicia faba. Plant Physiol 2001;126:1438-48. 